\title{
OPEN Radiofrequency EMF irradiation effects on pre-B lymphocytes undergoing somatic recombination
}

\begin{abstract}
Elena Ioniță ${ }^{1,2}$, Aurelian Marcu ${ }^{3}$, Mihaela Temelie ${ }^{1}$, Diana Savu ${ }^{1}$, Mihai Şerbănescu $^{3}$ \& Mihai Ciubotaru ${ }^{1,2} \bowtie$

Intense electromagnetic fields (EMFs) induce DNA double stranded breaks (DSBs) in exposed lymphocytes.We study developing pre-B lymphocytes following $V(D) J$ recombination at their Immunoglobulin light chain loci (IgL). Recombination physiologically induces DNA DSBs, and we tested if low doses of EMF irradiation affect this developmental stage. Recombining pre-B cells, were exposed for $48 \mathrm{~h}$ to low intensity EMFs (maximal radiative power density flux $\mathrm{S}$ of $9.5 \mu \mathrm{W} / \mathrm{cm}^{2}$ and electric field intensity $3 \mathrm{~V} / \mathrm{m}$ ) from waves of frequencies ranging from 720 to $1224 \mathrm{MHz}$. Irradiated pre-B cells show decreased levels of recombination, reduction which is dependent upon the power dose and most remarkably upon the frequency of the applied EMF. Although $50 \%$ recombination reduction cannot be obtained even for an $\mathrm{S}$ of $9.5 \mu \mathrm{W} / \mathrm{cm}^{2}$ in cells irradiated at $720 \mathrm{MHz}$, such an effect is reached in cells exposed to only $0.45 \mu \mathrm{W} / \mathrm{cm}^{2}$ power with 950 and $1000 \mathrm{MHz}$ waves. A maximal four-fold recombination reduction was measured in cells exposed to $1000 \mathrm{MHz}$ waves with $\mathrm{S}$ from 0.2 to $4.5 \mu \mathrm{W} / \mathrm{cm}^{2}$ displaying normal levels of $\mathrm{yH} 2 \mathrm{AX}$ phosphorylated histone. Our findings show that developing B cells exposure to low intensity EMFs can affect the levels of production and diversity of their antibodies repertoire.
\end{abstract}

Somatic or V(D)J recombination is the process that assembles in all jawed vertebrates the gene segments encoding the variable regions of the specific antigen immune receptors ( $\mathrm{T}$ cell and Immunoglobulin IG) of the lymphoid $\mathrm{T}$ and $\mathrm{B}$ cells ${ }^{1}$. This process occurs in lymphocyte precursors, is mediated by RAG (recombination activating gene proteins) recombinase a heterotetrameric complex made of a dimer of RAG1 and two monomers of RAG2 $2^{2,3}$. RAG1 a member of the DDE transposase/Integrase family is the key catalytic component of RAG. RAG binds specifically to recombination signal sequences (RSS) flanking germinal coding V, (D), J gene segments in the variable region at the IG and $\mathrm{T}$ cell receptor loci and catalyzes their rearrangement ${ }^{4}$. RAG recombination generates two DNA hairpins at the coding ends and two blunt double stranded DNA cuts at the signal ends. RAG maintains the paired cleaved ends in proximity and allows the ubiquitous set of non-homologous end-joining (NHEJ) DNA repair enzymes (Artemis, ATM, DNAPk, XRCC4, DNA Ligase IV) to resolve the hairpins and join the cleaved ends. For $\mathrm{B}$ and $\mathrm{T}$ lymphocytes recombination occurs at two stages during their differentiation ${ }^{5}$. We will discuss only the B lineage development in the bone marrow. First two rounds, D to J (in pre-pro stage) followed by $\mathrm{V}$ to $\mathrm{DJ}$ recombination (in late-pro stage) occur in pro-B cells at their Ig Heavy chain locus $(\mathrm{IgH})$. Once $I g H$ locus is rearranged, expressed Ig $\mu$ together with a surrogate light chain comprising $\lambda 5$ Vpre B proteins and two Iga, $\beta$ signaling subunits assemble the pre-B cell receptor(pre-BCR) ${ }^{6}$, which marks the large pre-B cell stage. Stromal bone marrow cells secreted interleukin IL-7 binds to their receptor (IL-7R), a signal which is transduced as pro-survival and proliferative ${ }^{7}$. First, IL-7R signals through Janus Kinase $3-(J A K-3)^{8}$ phosphorylating and recruiting the signal transducer and activator of transcription $5 \mathrm{~A}$ and B (STAT5A and B) ${ }^{9,10}$ which stimulate transcription of Ccnd3 encoding Cyclin D $3^{11}$ and of the B cell lymphoma 2(bcl2) gene ${ }^{12}$. Both Cyclin D3 and the anti-apoptotic BCL2 help pre-B cells through cell cycle G1 checkpoint allowing the replication of their DNA. Secondly, IL-7R signals in large pre-B cells through phosphoinositide 3 -kinase $(\mathrm{PI} 3 \mathrm{~K})^{13}$ and protein Kinase B (AKT) phosphorylating the forkhead box O 1, 3 (FOXO1,3) transcription factors, modification which exports them from nuclei and targets the proteins for degradation ${ }^{14-16}$. FOXO1, 3 activate $e$-rag enhancer and rag1, 2 genes transcription ${ }^{14,17}$. In large pre-B cells IL-7R also signals via the nuclear factor kappa light chain

${ }^{1}$ Department of Physics of Life and Environmental Sciences, Horia Hulubei National Institute for R\&D in Physics and Nuclear Engineering, 077125 Măgurele, Ilfov, Romania. ${ }^{2}$ Department of Immunology, Internal Medicine, Colentina Clinical Hospital, 72202 Bucharest, Romania. ${ }^{3}$ Center for Advanced Laser Technologies, National Institute for Laser Plasma and Radiation Physics, 077125 Măgurele, Ilfov, Romania. ${ }^{\varpi}$ email: mihai.ciubotaru@ nipne.ro 
enhancer of activated B cells (NF-kB) stimulated by AKT phosphorylation of IKKa serine $23^{18}$. NF-kB activates Cyclin D4 kinase which targets FOXO1 for phosphorylation and repression ${ }^{19}$. By inhibiting FOXO1, or phosphorylating STAT-5, IL-7R signals are transiently downregulating RAG proteins in large pre-B cells. After four to five rounds of replication the large pre-B lymphocytes get under the influence of cell surface pre-BCR receptor aggregation and stimulation (in absence of a bonified ligand), a signal which antagonizes that of IL-7R, induces cell cycle arrest and transitions cells towards small pre-B stage ${ }^{20}$. Stimulation of pre-BCR cascades through RAS and extracellular signal- regulated kinase (ERK) upregulating the E2A transcription factor expression. E2A binds both Igk intronic and Igk 3' enhancers making the Igk light chain locus accessible for recombination ${ }^{21}$. Another effect of pre-BCR stimulation signals through spleen tyrosine kinase(SYK) and B cell-linker protein(BLNK) which together repress PI3K and AKT but stimulate mitogen activated p38 kinase which activates FOXO1 to express $\mathrm{RAG}^{13,20,22}$. Consequently, in small pre-B cells subsequent $\mathrm{V}$ to J rearrangements occur at $\operatorname{Ig} L k$ or $\lambda$ light chain loci. Upon completion of a successful $\mathrm{V}$ to $\mathrm{J}$ recombined allele, the cell develops into naïve immature $\mathrm{B}$ cell, exposing IgM B cell receptors (BCR).

Interference of $\mathrm{V}(\mathrm{D}) \mathrm{J}$ recombination with other concurrent exogenous factors favoring DNA DSBs, like ionizing or EM irradiation can induce DNA damage which may lead to oncogenic translocations such as those described in acute lymphoblastic leukemia (ALL) ${ }^{23,24}$. Exposure of human blood lymphocytes from healthy donors to strong EMFs ( $2 \mathrm{~h}$ irradiation with sinusoidal pulses at $4 \times 10^{5} \mathrm{~V} / \mathrm{m} 50 \mathrm{~Hz}$ with a carrier wave of 10 $\mathrm{Hz}^{25}$ ) causes DNA DSBs and chromosomal lesions whose severity correlate with the intensity of the applied fields and the duration of exposure. However, less clear results come from studies with irradiated lymphocytes using low intensity, high radiofrequency(RF) EMFs $(3 \mathrm{kHz}-300 \mathrm{GHz})^{26}$. Most of these studies have assessed the levels of EMF inflicted DNA single and DSBs on lymphocytes using the microgel electrophoresis technique or 'comet assay', which detects brakes with a sensitivity limit of 50 strand events per diploid cell ${ }^{27}$. RF EM irradiation from cell phones was first studied by Phillips et al. in Molt-4 human lymphoblastoid cells exposed for 2-21 h to fields of 813.5 and $836.5 \mathrm{MHz}$ with specific absorption rate (SAR) $(2.4-26 \mu \mathrm{W} / \mathrm{g})^{28}$. Variable degree of DNA damage is reported, mainly induced by high SAR values waves (increased at 24 or $26 \mu \mathrm{W} / \mathrm{g}$ and decreased at 2.4 or $2.6 \mu \mathrm{W} / \mathrm{g}$ ) and longer exposures $\left(21 \mathrm{~h}\right.$ versus $2 \mathrm{~h}$ ). Another study by Mashevich et al. ${ }^{29}$ reveals that continuous $72 \mathrm{~h}$ exposure of human peripheral blood lymphocytes to EMFs of $830 \mathrm{MHz}$ waves, with SAR ranging from 1.6 to $8.8 \mathrm{~W} / \mathrm{kg}$ lead to SAR dependent aneuploidy with specific abnormalities on chromosome 17 . However, in vitro exposure of human blood lymphocytes for only $2 \mathrm{~h}$ to short pulses of $2450 \mathrm{MHz}$, at an average power of $5 \mathrm{~mW} /$ $\mathrm{cm}^{2}{ }^{30}$ showed no significant DNA damage as assessed by alkali comet assays. No signs of genotoxicity were found when total human blood leukocytes were in vitro exposed for $24 \mathrm{~h}$ either at a continuous or a pulsed-wave $1.9 \mathrm{GHz}$ EMF with a SAR ranging between 0.1 and $10 \mathrm{~W} / \mathrm{Kg}^{31}$. Absence of significant DNA damage response in human blood lymphocytes was also reported by a study by Stronati et al. ${ }^{32}$ in which blood specimens were continuously exposed for $24 \mathrm{~h}$ at a Global System Mobile Communication generated EMF of $935 \mathrm{MHz}$ with a SAR of 1 or $2 \mathrm{~W} / \mathrm{Kg}^{32}$. Similar negative results with respect to EMF induced DNA damage was reported in a study by Hook et al. ${ }^{33}$ with cultured Molt- 4 human lymphoblasts exposed for $24 \mathrm{~h}$ to four types of frequency mobile network modulations around $815-850 \mathrm{MHz}$ with SAR values ranging from 2.4 to $3.2 \mathrm{~W} / \mathrm{Kg}{ }^{33}$.

In our work we test the effects of in vitro irradiating $\mathrm{V}(\mathrm{D}) \mathrm{J}$ recombining pre-B cells with very low doses of RF EM waves. RAG stimulation is obtained either mimicking a pre-BCR stimulus with AKT inhibition, or with a stress inducible Abelson (Abl) kinase inhibitor response via STAT5 phosphorylation inhibition. For both stimuli, near 950-1000 MHz RF EMF cell irradiation, in the absence of detectable DNA DSBs, causes a four-fold reduction in recombination levels in exposed pre-Bs versus that assessed in non-irradiated cells.

\section{Results}

Design and specific experimental conditions used to assess $/ g$ locus rearrangements. Our study tests how gene recombination levels are influenced by exposure to EMFs with distinct emitted frequencies and power levels (dose-response). In vitro grown vAbl transformed murine pre-B cells stimulated to recombine $\mathrm{V}(\mathrm{D}) \mathrm{J}$ are exposed to a broadband $(0.8-3 \mathrm{GHz})$ emission antenna which broadcasts an EMF from a RF generator (Fig. 1A upper region). For all experiments we standardized our cellular growing conditions to control irradiation parameters (see Supplemental Material section S1 and Fig. 1Sa and b). RAG expression and V(D)J recombination can be induced in vAbl transformed pre-B cells(differentiating them in small pre-B cells) upon stimulation either with an Abl tyrosine kinase inhibitor imatinib(mesylate of imatinib)(IMA) ${ }^{34,35}$ (Supplemental Material Fig. 1Sb growing dish wells 1, 2 and 3), or with an AKT inhibitor GSK-690693(GSK) ${ }^{19}$ (wells 4, 5 and 6, Fig. 1Sb). Whereas IMA induces RAG by inhibiting vABL-1 tyrosine kinase via a stress-inducible GADD45 $a$ action ${ }^{17,34,35}$, GSK acts as AKT inhibitor, reducing NF-kB and FOXO1 inhibitory phosphorylation (by CDK4) thus, mimicking a physiologic pre-BCR stimulation ${ }^{19}$ (see Supplemental material section S2). Time course experiments with RAG induction in vAbl pre-B cells using both drugs show maximal RAG1 levels after $36 \mathrm{~h}$ of stimulation (see Supplemental material S2 and Fig. 2Sa and b). Using this finding, after $48 \mathrm{~h}$ post drug induction (to allow recombination), all synchronized cultured cells were harvested and their genomic DNA extracted. A previously described two-steps nested PCR (polymerase chain reaction) which assesses the recombination extent taking place at Igk kappa light chain locus (chromosome 6, locus schematic and primer positions shown in Fig. 1B), is templated with the equivalent genomic DNA extracted from $2 \times 10^{6}$ cells from each tested culture set ${ }^{36,37}$. In the absence of $\mathrm{V}(\mathrm{D}) \mathrm{J}$ recombination (control reactions with no stimulation Fig. 1C lane 2) the variable region $\mathrm{V}$ and $\mathrm{J}$ segments in germline configuration are too far apart on the chromosome to yield appropriate amplification products. The PCR amplification products obtained only from recombined templates (Fig. 1C lane 3) are separated after electrophoretic migration on $1.5 \%$ agarose gels and visualized after fluorescent staining with SYBR green (schematic lower drawing Fig. 1A, and gel scan Fig. 1C). This typical nested PCR reaction reports $k$ locus recombination events with two detectable products; the predominant one Vk-Jk2 of $280 \mathrm{bp}(95 \%)$ and Vk-Jk1 of 


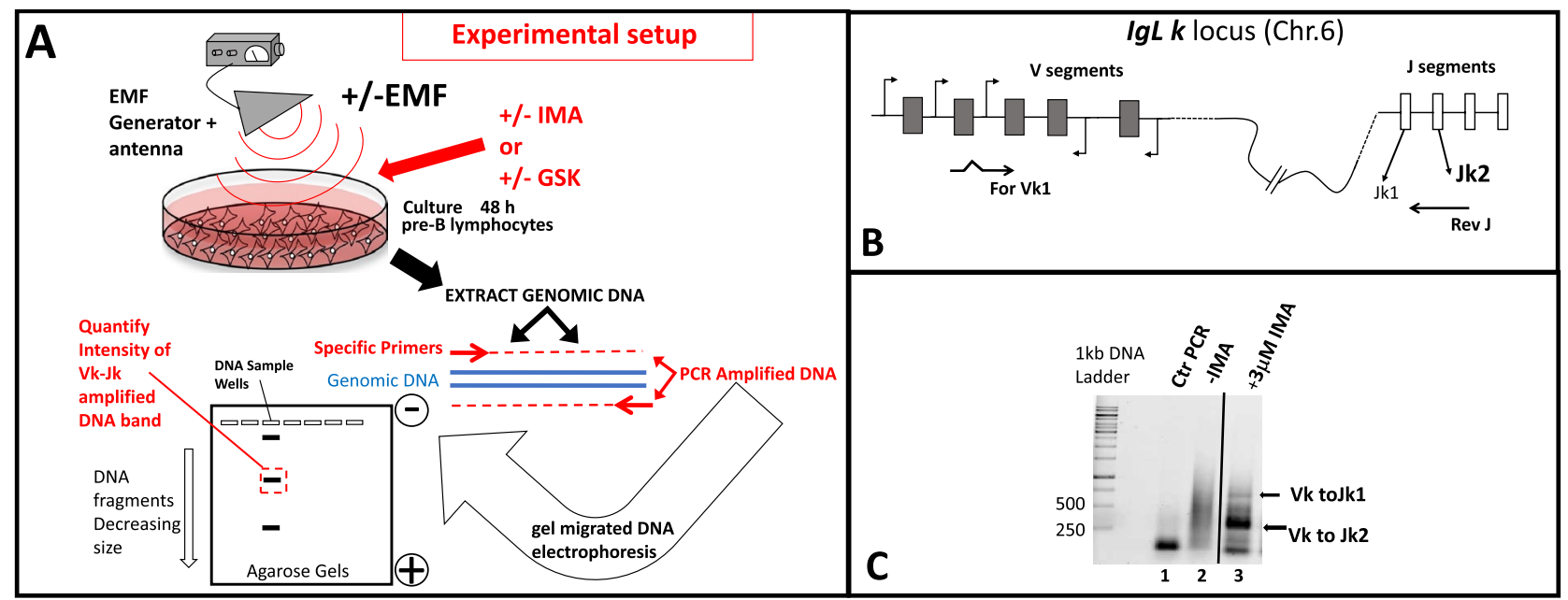

Figure 1. (A) Schematic depiction of the flow chart of the experimental design. Murine A-70 vAbl pre-B cells grown with or without exposure to Electromagnetic field influence(EMF), in the absence or presence of RAG stimulation either by Mesylate of Imatinib (IMA) or by GSK-690693(GSK), are harvested and their genomic DNA subjected to a two-steps PCR recombination assay identifying Vk to Jk rearrangements at their IgL kappa loci. The electrophoretically separated recombination products (Vk-Jk) are quantified by densitometry to assess the extent of locus rearrangements influenced by EMF. (B) Shematic configuration of IgL $k$ kappa locus on Mouse chromosome 6, and the positioning of the primers used in the assay. (C) PCR reactions electrophoretically separated in agarose gel stained with Sybr green identify the recombined products (arrows show Vk to Jk1 and Vk to Jk2) in lane 3 versus, control reactions lane 1 without genomic DNA, lane 2 templating genomic DNA from uninduced cells (in germline configuration). Such recombination amplified reactions are then used for densitometry quantifications. The entire gel from which (C) was cropped displaying amplifications (Vk to Jk response) from cells treated with a wide range of increasing IMA concentrations, is shown in Supplemental Material Fig. 3Sa.

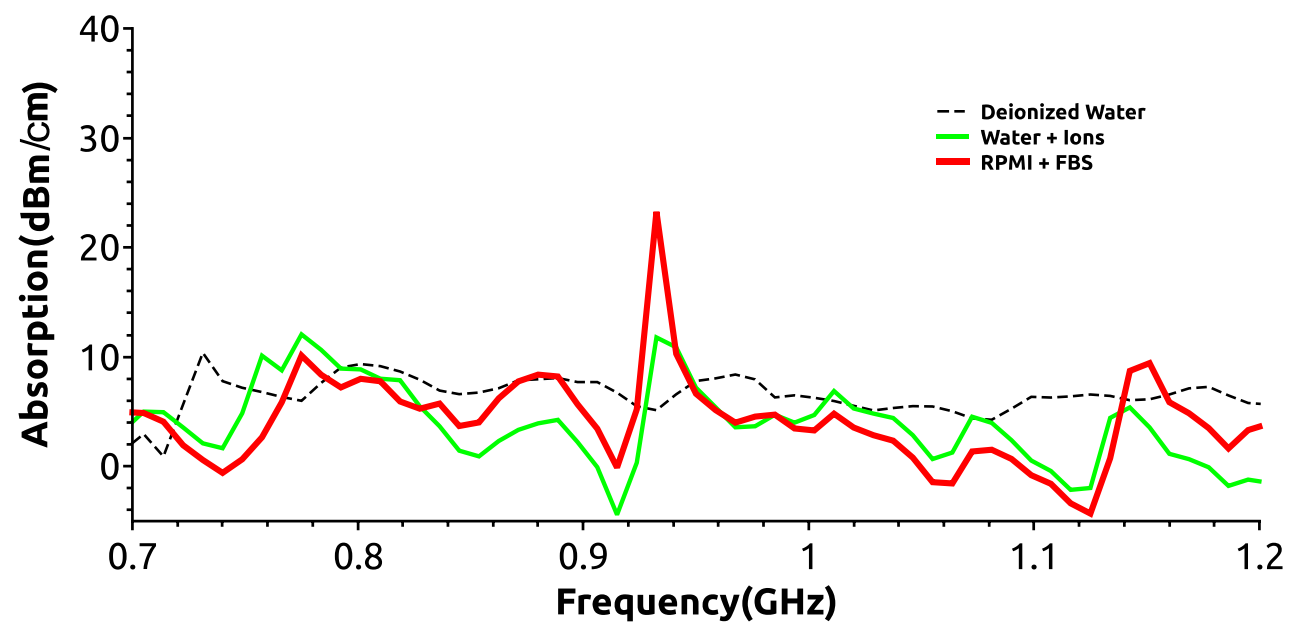

Figure 2. Absorption spectra measurements of filtered deionized water (dashed thin black line), tap water (green thick line Water + Ions) and RPMI cell culture medium with $10 \%$ fetal calf serum (FBS)(red thick line RPMI+FBS) All measurements were done using a Keysight-AGILENT-HP N9935A spectrum analyzer as described in "Methods" section.

$700 \mathrm{bp}(5 \%)^{36}$ (Fig. 1C lane 3). Densitometric quantifications of the DNA Vk-Jk2 recombination products allow us to assess the EMF influence on recombination (Fig. 1A lower drawing). A dose-response (recombination) effect obtained with increasing IMA concentrations in $48 \mathrm{~h}$ stimulated pre-B cells is shown in supplementary Fig. 3Sa, gel and quantified data from three such experiments shown in Fig. 3Sb histograms. The lowest drug concentration ( $3 \mu \mathrm{M}$ for IMA and of $10 \mu \mathrm{M}$ for GSK,) for which maximal recombination effects are obtained, is used for each drug in our irradiation assays. For linear range quantifications of the image scans each reaction uses genomic DNA template at least at three distinct dilutions from the cellular extraction stock solution and the final result may be reported as an average of the three quantified products values corrected by the histone $\mathrm{H} 1$ band intensity of the corresponding sample. In Supplemental material in Fig. 3Sc an 3Sd a set of nested PCR 
A

IMA $++++--\cdot-$

GSK - - - ++++-

$\mathrm{EMF}+\boldsymbol{+}+-\quad+++$

Exp. Well $3 \begin{array}{llllll}3 & 2 & 1 & 6 & 5 & 4\end{array}$

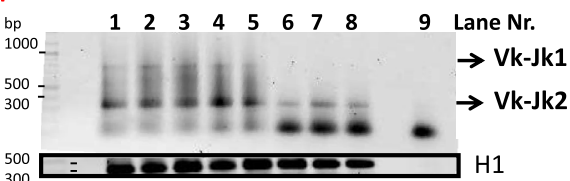

300

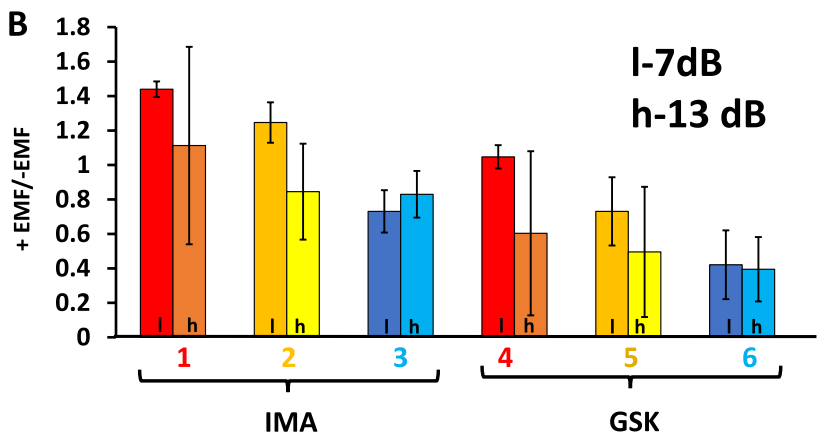

Figure 3. A two steps PCR recombination assay is used to identify Vk to Jk1 or Vk to Jk2 rearrangements from pre-B cells upon RAG induction with Imatinib or GSK. (A) A Sybr Green stained 1.5\% Agarose TBE gel in which the recombination PCR reactions templated with initial 1:5 dilutions of genomic DNA extracted from each distinct cell treatment lot $\left(2 \times 10^{6}\right.$ cells $)$ are electrophoretically resolved. The cells were either unexposed (gel reaction lanes 4 and 5) or subjected for $48 \mathrm{~h}$ to $1 \mathrm{GHz}$ EMF irradiation (lanes 1 to 3 and 6 to 8) with the generator setting at $13 \mathrm{dBm}$. The color code designating the positions of exposed EMF (exp.Well) wells in the dish is the same with the one used in supplementary Fig. 1Sb. Last lane (9) of the gel, -DNA control reaction. The bottom black box (cropped from a distinct gel) displays Hisone H1 PCR reactions templated with the same amount of genomic DNA as the recombination reactions above(control genomic DNA). (B) Identified Vk to $\mathrm{Jk} 2$ recombined products were quantified from scanned gels corresponding to PCR reactions from cells $+/-$ Irradiation and the calculated ratios of band intensities expressed +EMF/-EMF(irradiated/nonexposed) for each well (color code consistent with that shown in Fig. 1S). The histograms represent the average values of three independent quantified experiments. EMF-Electromagnetic Field, Recombination pharmacological stimuli (Imatinib, IMA) versus (GSK-690693, GSK). H1, histone H1 control reaction PCR reactions. Darker font histograms correspond to lower $7 \mathrm{dBm}(\mathrm{l})$ and brighter to higher $13 \mathrm{dBm}(\mathrm{h})$ generator power settings.

reactions templated with serial dilutions of input genomic DNA from IMA stimulated cells, followed by quantitation of the signal are shown to illustrate that the assay responds linearly in its amplified Vk-Jk2 band intensity.

EM wave absorption spectrum of the cell culture medium. We measured how the EM waves with frequencies ranging from 700 to $1224 \mathrm{MHz}$ are absorbed by the fetal bovine calf serum supplemented cell culture medium (RPMI + FBS in Fig. 2) in which the pre-B cells are cultured. For comparison only absorption measurements were also performed for deionized water (conductivity $<5 \mu \mathrm{S} / \mathrm{cm}$ ), and for ions containing unfiltered tap water samples (see Methods Water + ions, Fig. 2). The measurements were done using a setup in which an emission and a reception horn antenna were spaced $1 \mathrm{~m}$ apart with the liquid sample container positioned in the vicinity $(1 \mathrm{~cm})$ of the later (see Supplemental material Fig. 4S). The emission antenna was connected to a generator and signals from the receiver antenna were collected and recorded by a standard spectrum analyzer. In Fig. 2 are presented the background corrected absorption spectra per $1 \mathrm{~cm}$ width of each liquid sample measured. A well-defined absorption peak is observed at $938 \mathrm{MHz}$ for the RPMI + FBS medium sample which is twice as large as the others measured at this frequency. All samples have similar absorption values for the rest of the tested spectral frequencies. This finding is important since the range of frequencies $(720 \mathrm{MHz}, 850 \mathrm{MHz}$, $950 \mathrm{MHz}, 1 \mathrm{GHz}$ and $1.2 \mathrm{GHz}$ ) to be used for cell irradiation centers our window of exposure between $950 \mathrm{MHz}$ and $1 \mathrm{GHz}$, proximal to the maximal culture medium absorption peak.

To test how the cell growing medium affects the electric intensity of the exposing fields, EMF electric flux density (D displacement) measurements were made inside the incubator for each mentioned frequency, in the absence or presence of culture medium in the culture plate (Supplemental Material S3 and Fig. 5S). Values greater than one of the $\mathbf{D}_{\mathrm{m}} / \mathbf{D}_{\text {air inc }}(1.8-1.95)$ ratios measured between 750 and $1000 \mathrm{MHz}$ (Supplemental material section $\mathrm{S} 3$ and Fig. $5 \mathrm{Sc}$ ) show in this range, the complete RPMI + FBS cell growing medium selectively potentiates the developed fields.

EMF irradiation effects on $\mathrm{V}(\mathrm{D}) \mathrm{J}$ recombination in $\mathrm{v}-\mathrm{Abl}$ pre-B cells. Murine vAbl pre-B cells were grown under normal conditions or stimulated either with $3 \mu \mathrm{M}$ IMA or with $10 \mu \mathrm{M}$ GSK in the presence/ absence of an antenna which emits a generator controlled EMF from waves of $720 \mathrm{MHz}, 850 \mathrm{MHz}, 950 \mathrm{MHz}$, 
$1 \mathrm{GHz}, 1.224 \mathrm{GHz}$ each with 7 or $13 \mathrm{dBm}$ output power setting. For all exposures, the antenna was held at $2.4 \mathrm{~cm}$ above the composite 6 wells plate as depicted in Supplemental material Fig. 1Sb (lower profile drawing) consistently keeping it in the same location with respect to the incubator walls (Supplemental material S1 and Fig. 1S). Cells were grown +/- EMF constant continuous exposure for $48 \mathrm{~h}$ with +/- IMA or +/- GSK. In Fig. 3A is shown a gel with resolved reactions either from nonexposed cells (lanes 4 and 5) or from cells continuously subjected for $48 \mathrm{~h}$ to the influence of $1 \mathrm{GHz}$ fields (gel for generator set at $13 \mathrm{dBm}-\mathrm{h}$ ), with both RAG induction treatments (plate Exp. wells IMA 1, 2, 3 and GSK- 4, 5, 6 with color code shown in Supplemental material Fig. 1Sb). Visually one can see, a reduction of $\mathrm{Vk}$ to $\mathrm{Jk} 2$ recombination products obtained in reactions from irradiated cells versus those from similarly drug induced, non-irradiated cells (see Fig. 3A compare lane 4 non-irradiated to reactions in lanes 1-3 exposed for IMA, and lane 5 unexposed to lanes 6-8 from irradiated GSK stimulated cells). The irradiating effects are most pronounced in the plate wells closest to the actively emitting antenna elements $(\lambda / 2$ for $1 \mathrm{GHz}$ waves use as main element the $15 \mathrm{~cm}$ one located near wells 3 and 6 (Supplemental material Fig. 1Sb) hence, recombination reduction for plate Exp. wells 3, $6>2,5>1,4$ or correspondingly gel lanes $1,6>2,7>3,8$ ). The value of the calculated ratios between recombination Vk-Jk2 PCR band intensities obtained from irradiated/ non-irradiated(+EMF/-EMF) cells for all tissue culture wells are shown as histograms in Fig. 3B. Values less than one show specific Vk-Jk2 recombination reduction associated with EMF irradiation.

Similar experiments were performed with EMF exposures at 720, 850, 950, 1000 and $1224 \mathrm{MHz}$ (each frequency centers on a different antenna element), generator setting either at $7 \mathrm{dBm}$ or $13 \mathrm{dBm}$. To display a wider palette of EMF dose exposure values we summed up the data from all of the wells in Fig. 4 which displays cell Vk-Jk2 recombination Fractions(+EMF/-EMF -ordinates), against logarithm of measured irradiating power flux density $S$ values ( $\mu \mathrm{W} / \mathrm{cm}^{2}$-abscissas) at each location. Each row of the two panels is for a distinct frequency with panels for each drug located on the same column: Fig. 4A(GSK- left) and B(IMA- right). Consistently all diagrams show power dependent reduction in cellular $\mathrm{Vk}-\mathrm{Jk} 2$ recombination. S values into the emitting antenna were calculated from antenna recorded voltages, circuit impedance, and antenna constructive elements dimensions and reflect $S$ in the air inside incubator, surrounding the involved culture well. In each panel with dotted black lines we pointed the EMF power dose required to induce a two-fold Vk-Jk2 recombination reduction from that of the non-irradiated lot (+EMF/-EMF $50 \%$ reduction shown as 0.5 ratio for Vk-Jk2, Cellular Recombination Fraction). In Fig. 4 when 50\% recombination reduction (exposed versus non-irradiated cells) is not reached, the minimal recombination ratios obtained and their inducing $S$ levels are shown in parenthesis. The most remarkable finding of our study is that even for such a small window of frequencies (between 720 and $1224 \mathrm{MHz}$ ), the power dose-response effect is dramatically influenced by the frequency of the irradiating EMF. If at $720 \mathrm{MHz}$ one reaches a $0.56 / 0.70$ maximal recombination reduction for $9.49 \mu \mathrm{W} / \mathrm{cm}^{2}$ exposure, similar reduction in recombination effects are obtained at $950 \mathrm{MHz}$ and $1 \mathrm{GHz}$ with only $1 / 15$ th respectively $1 / 20$ th $(0.63$ or $0.43 \mu \mathrm{W} /$ $\mathrm{cm}^{2}$ ) the power used at $720 \mathrm{MHz}$. The power dose-cell recombination response curves at $950 \mathrm{MHz}$ and $1 \mathrm{GHz}$ EMFs show by far the most accentuated measured effects (for both drugs). For GSK at $1 \mathrm{GHz}$ irradiation, an almost four-fold decrease in $\mathrm{V}(\mathrm{D}) \mathrm{J}$ recombination (from 0.90 to 0.22 ) is observed over a moderate increase in $\mathrm{S}$ exposure from 0.1 to $4.53 \mu \mathrm{W} / \mathrm{cm}^{2}$ (see second from the bottom panel in Fig. 4A GSK $1000 \mathrm{MHz}$ ). Both curves in Fig. 4 for $1 \mathrm{GHz}$ display an abrupt recombination decrease at a small increase in $\mathrm{S}\left(0.25-1 \mu \mathrm{W} / \mathrm{cm}^{2}\right)$ after which the cellular effect plateaus out over a larger window of higher exposure power $S$ values $\left(1-4.5 \mu \mathrm{W} / \mathrm{cm}^{2}\right)$. To emphasize the influence of EMF frequency Table 1 shows how recombination fractions (+EMF/-EMF) vary at a relatively constant $\approx 1.5 \mu \mathrm{W} / \mathrm{cm}^{2}$ irradiating power flux density S exposure level for all tested EMF frequencies. At this small irradiating power no effect is detectable at $720 \mathrm{MHz}$, whereas at $950 \mathrm{MHz}$ a two-fold recombination reduction is measured reaching almost three-fold recombination inhibiton at $1 \mathrm{GHz}$.

To circumvent the cellular growing medium polarization effects (which significantly change polarity at $720 \mathrm{MHz}$ and above $1100 \mathrm{MHz}$, Supplemental material 3S and Fig. 5Sc) or its enhanced wave absorption at $938 \mathrm{MHz}$ (Fig. 2), we intentionally represented in Fig. 5 the recombination fractions for two constant electric field intensity E exposure values, measured inside the medium; one of $0.4 \mathrm{~V} / \mathrm{m}$ (Fig. 5A.) and the other of $0.6 \mathrm{~V} / \mathrm{m}$ (Fig. 5B). The approximative intensity of the emitted electric field was calculated in the cell medium from the measured electric flux density $\left(\mathbf{D}_{\mathrm{m}}\right.$ displacement) values ${ }^{38}$ described in the previous section, and averaged for the central plate well. For both E values and both pharmacological stimuli (IMA-red and GSK-blue) the most accentuated plots concavities (maximal irradiation induced recombination reduction effect), correspond to $950-1000 \mathrm{MHz}$. At both $\mathrm{E}$ values represented in Fig. 5 the recombination ratios are unaffected by EMFs at $720 \mathrm{MHz}$. In contrast, at $1000 \mathrm{MHz}$, a two-fold reduction is observed for the $0.4 \mathrm{~V} / \mathrm{m}$ EMF intensity, and a three (IMA) to four-fold (GSK) decrease is measured at the stronger $0.6 \mathrm{~V} / \mathrm{m}$ field exposure. The electric fields dose exposures -recombination reduction effects in Fig. 5 and those reported for EMFs power dose exposures in Fig. 4 are qualitatively similar. These data strongly suggest that exposure even to very low irradiation doses from specific $900-1000 \mathrm{MHz}$ radiofrequency waves dramatically affect in irradiated pre-B cells the efficiency of $\mathrm{V}(\mathrm{D}) \mathrm{J}$ recombination at their Ig kappa locus.

Histone H2AX phosphorylation shows no detectable DNA DSB damage cell response in EMF exposed pre-B cells. We asked whether the observed EMF irradiating effects on V(D)J recombination are due to DNA damage and presence of unrepaired DSBs. Impairment of DNA integrity can be assessed by the extent with which irradiation induces $\mathrm{H} 2 \mathrm{AX}$ histone phosphorylation $(\gamma \mathrm{H} 2 \mathrm{AX})$, a process associated with DNA DSBs and their intranuclear repair. The nuclear $\gamma \mathrm{H} 2 \mathrm{AX}$ repair foci are the fairest indication that the NHEJ DNA repair machinery acts properly in these cells repairing DSBs caused by any DNA lesion-causing agent ${ }^{39,40}$. We grew cells under similar stimulation (+/- IMA, +/- GSK) and +/- EMF irradiation conditions (7 dBm or $13 \mathrm{dBm}$ generator power settings at $950 \mathrm{MHz}$ ) with those described above but instead of extracting DNA, the harvested cells were fixed and doubly stained: (a) with Hoechst 33342 dye (for nuclear total DNA staining in 


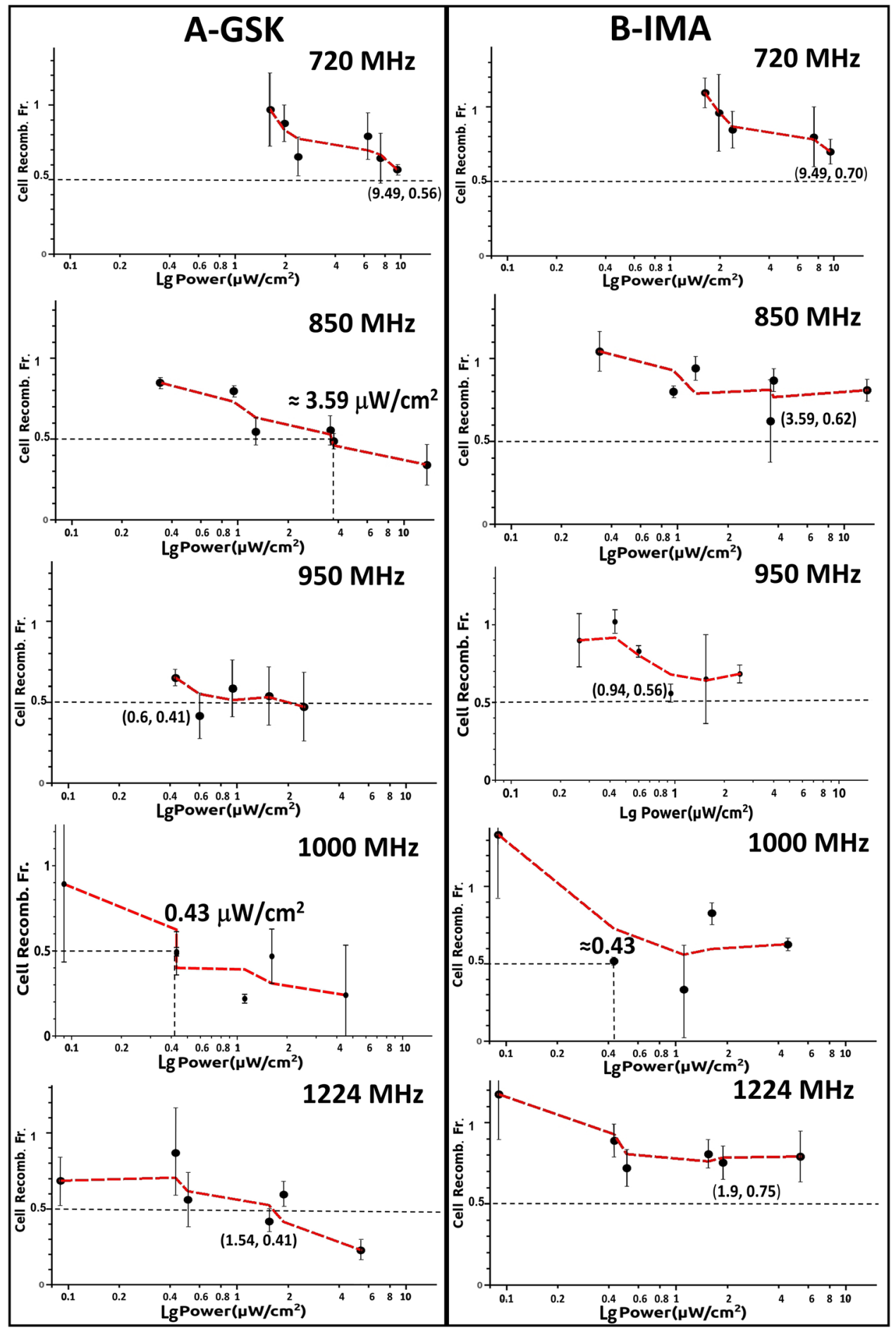

Figure 4. The EMF power dose-cell recombination response curves at 720, 850, 950, 1000 and $1224 \mathrm{MHz}$ for both types of pharmacological agents stimulating RAG expression (A) (GSK-690693, GSK), and (B) (Imatinib, IMA). Cell Recomb. Fr. expresses the ratio values of measured Vk-Jk2 recombination quantified from cells grown in + EMF/-EMF (irradiated/non-exposed) conditions. Bottom abscissa displays logarithm of $S$ power flux density values (Power $\mu \mathrm{W} / \mathrm{cm}^{2}$ ) measured around the emitting antenna inside the $\mathrm{CO}_{2} 5 \mathrm{vol} \%$, and $95 \%$ water humidity incubator air conditions, expressed as a single range in all panels(logartithmic scale). The black dotted line denote a level of EMF induced two-fold recombination reduction (Cell recomb. Fr. $=0.5$ ), whereas when this level is not reached in the experiment the coordinates of the lowest obtained Cell Recomb. Fr. are given. The red dotted line connecting markers is just a Moving Window Average line which accounts for the average between successive data points displaying the trend of data variation. The error bars represent standard deviation (SD) values from three independent experiments. 


\begin{tabular}{|l|l|l|}
\hline \multicolumn{3}{|l|}{$\begin{array}{l}\text { Fraction recombination+EMF/-EMF (EMF } \\
\left.\text { at } \mathbf{S} \approx \mathbf{1 . 5} \boldsymbol{\mu} \mathbf{W} / \mathbf{c m}^{2}\right)\end{array}$} \\
\hline \multirow{2}{*}{ Frequency $(\mathbf{M H z})$} & \multicolumn{2}{l}{ Response stimulus } \\
\cline { 2 - 3 } & GSK & IMA \\
\hline 720 & $0.97 \pm 0.2$ & $1.09 \pm 0.1$ \\
\hline 850 & $0.56 \pm 0.1$ & $0.8 \pm 0.1$ \\
\hline 950 & $0.53 \pm 0.2$ & $0.65 \pm 0.3$ \\
\hline 1000 & $0.38 \pm 0.1$ & $0.46 \pm 0.3$ \\
\hline 1224 & $0.41 \pm 0.1$ & $0.8 \pm 0.1$ \\
\hline
\end{tabular}

Table 1. Lists the measured cell recombination fraction (+EMF/-EMF) at a relative constant power flux density $S$ value of $1.5 \mu \mathrm{W} / \mathrm{cm}^{2}$ for all tested frequencies.
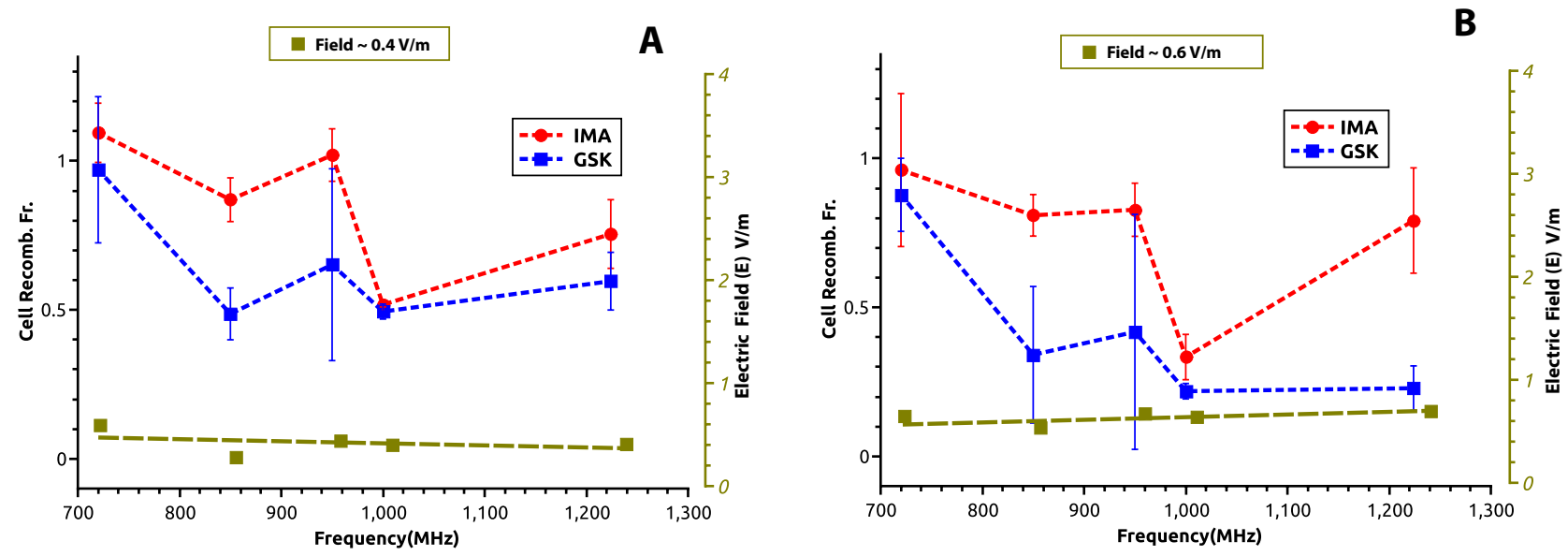

Figure 5. Variation of cell recombination fraction (+EMF/-EMF) with the field irradiation frequency shown in each panel for a constant receiver EMF electric intensity field E calculated in the cell culture medium. (A) EMF electric field intensity E $0.4 \mathrm{~V} / \mathrm{m}$, (B) EMF electric field intensity E $0.6 \mathrm{~V} / \mathrm{m}$. The pharmacological agents stimulating RAG expression GSK-690693, GSK-blue, and Imatinib, IMA-red. The pale green dotted line shows the relative constant distribution of measured electric field as a function of frequency. The error bars represent standard deviation $(\mathrm{SD})$ values from three independent experiments.

blue) and (b) immunofluorescently with anti $\gamma \mathrm{H} 2 \mathrm{AX}$ antibodies yielding a Cy2 green fluorescence which identifies DNA DSBs repairing $\gamma \mathrm{H} 2 \mathrm{AX}$ foci ${ }^{40}$ (see Methods). As a DNA DSBs control an extra lot of cells were either noninduced o similarly drug treated but instead of EMF they were subjected to a quick $1 \mathrm{~Gy}$, X ray irradiation dose prior to their harvest. Nine immunofluorescent images are shown in Fig. 6 A-I where blue contours show the cell nuclei and the green dots the DNA DSBs repairing $\gamma \mathrm{H} 2 \mathrm{AX}$ foci from: cells treated with +/- DMSO solvent control, +/- GSK, +/- IMA, +/- EMF set at $950 \mathrm{MHz}, 7 \mathrm{dBm}$ exposure and the control lot of cells exposed to $1 \mathrm{~Gy} \mathrm{X}$ ray. Such foci were also counted and their number reported per cell to a number of total 100 counted cells gathered from more than twenty successive field views for each experimental lot (shown as histograms in Fig. 6J for both $7 \mathrm{dBm}$ and $13 \mathrm{dBm}$ generator power settings). $1 \mathrm{~Gy}$ dose $\mathrm{X}$ ray irradiated cells are shown in Fig. 6B control with DMSO solvent, E with IMA, $\mathrm{H}$ with GSK and in $6 \mathrm{~J}$ the corresponding foci/cell counted histograms. All images (Fig. 6B,E,H) and the quantified histograms from X ray irradiated cells show similar and considerable DNA DSB lesions with consequent accumulation of $\gamma \mathrm{H} 2 \mathrm{AX}$ repair foci, regardless of the chemical stimulus used. On the contrary, the long $48 \mathrm{~h}$ EMF exposure experiments do not show signs of detectable unrepaired DNA DSB damage (Fig. 6C DMSO solvent, F with IMA and I with GSK, and counted foci/cells in Fig. 6J), above the background level of non-irradiated control cultures (Fig. 6A,D,G and ctrol. histograms in Fig. 6J). Exposing for $48 \mathrm{~h}$ cells to EMF, regardless of drug treatment, does not seem to inflict significant/ cumulative unrepaired DNA DSB lesions, (unlike those caused even by mild quick irradiation with 1 Gy dose of X rays). Only such DNA injuries could have caused a detectable accumulation of repairing $\gamma \mathrm{H} 2 \mathrm{AX}$ foci at the time of their harvest. Indirectly, these results suggest that the significant EMF induced reduction in pre-B cells recombination reported in Figs. 3B, 4, 5 and Table 1 is probably not caused by an enhanced level of accumulated unrepaired DNA DSBs.

\section{Discussion}

$\mathrm{V}(\mathrm{D}) \mathrm{J}$ recombination the central process in lymphocyte development physiologically generates DNA DSBs during its course, when cells become susceptible to external sources of DNA damage ${ }^{5}$. Our work tests how pre-B lymphocytes exposure to low dose EMFs of frequencies ranging from $720 \mathrm{MHz}$ to $1.2 \mathrm{GHz}$, used in utilitarian purpose telecommunication, affects the efficiency of their Igk loci rearrangements. First, we established a setup 


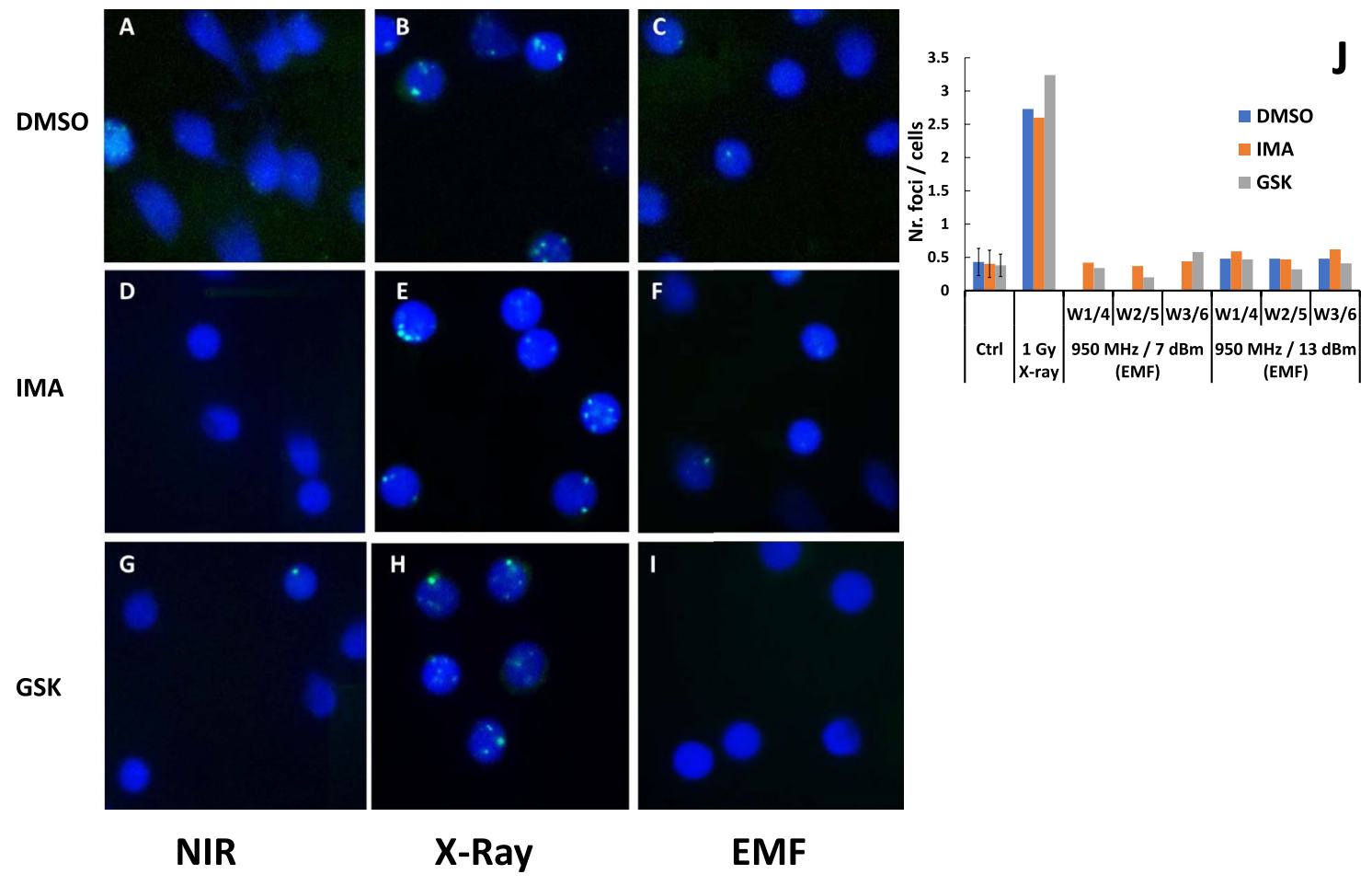

Figure 6. (A-I) Immuno-fluorescence detection of $\gamma \mathrm{H} 2 \mathrm{AX}$ phosphorylated histone foci in pre-B cells exposed to EMF or X ray irradiation. The $\gamma \mathrm{H} 2 \mathrm{AX}$ foci are shown in bright green $-\gamma-\mathrm{H} 2 \mathrm{AX}$, whereas DNA staining is in blue - nuclei. (A) Control solvent (DMSO) treated cells Nonirradiated (NIR); (B) Control (DMSO) treated 1 Gy X-ray irradiated cells(X-Ray); (C) Control (DMSO)treated EMF exposed (waves at $950 \mathrm{MHz}$, with emission generator power setting set at $7 \mathrm{dBm}-\mathrm{EMF}$ ); (D) IMA treated NIR; (E) IMA, X-ray; (F) IMA, EMF; (G) GSK, NIR; (H) GSK, X-ray; (I) GSK, EMF. (J) Number of counted foci per /cell represented as histograms. W1/4 refers to growing plate wells 1 and 4, W2/5 wells 2 and 5 and W3/6 wells 3 and 6 equivalent positions with respect to which cells were EMF irradiated, with generator power setting set at $7 \mathrm{dBm}$ and $13 \mathrm{dBm}$. GSK is cells treatment with $10 \mu \mathrm{M}$ GSK-690693, IMA their treatment with $3 \mu \mathrm{M}$ Imatinib. ANDOR camera assisted by IQ Live Cell Imaging software and foci analysis with Imaris for Cell Biologists software (both from OXFORD Instruments).

to control the EMF developed inside the cellular growing medium in a typical cell culture incubator. Cultured pre-B cells synchronously recombining V(D)J were EMF exposed during a $48 \mathrm{~h}$ window, which starts with RAG expression and ends with the NHEJ DSBs DNA repair ${ }^{5}$. A nested PCR assay is then used to study the cellular EMF irradiation gene effects.

The measured data in Figs. 3B, 4, 5 and Table 1 consistently show, EMFs cause a dose dependent reduction in $\mathrm{V}(\mathrm{D}) \mathrm{J}$ recombination in the irradiated pre-B cells, with similar effects for both RAG inducing stimuli (IMA or GSK) used. The magnitude of effects is tightly determined by the EMF frequency. A two-fold reduction in Vk-Jk2 recombination at $I g k$ locus narrowly can be obtained by an emitted S power value of $9.49 \mu \mathrm{W} / \mathrm{cm}^{2}$ at $720 \mathrm{MHz}$ (Cell Recomb. Fr. 0.56 for GSK and 0.7 for IMA), whereas this effect may be achieved by a field developing one twentieth of that $S$ dose at $1000 \mathrm{MHz}\left(0.5\right.$ Cell Recomb. Fr. for both drugs at $\left.0.43 \mu \mathrm{W} / \mathrm{cm}^{2}\right)$ (Fig. 4$)$. The recombination reduction although observed for all EMFs tested, seems to be maximal for 950 and $1000 \mathrm{MHz}$ waves, a small domain where the serum containing cell culture medium displays maximal EMF absorbance (Fig. 2), and augments by its molecular polarization the EMF electric intensity (supplementary Fig. 5Sc). We measured EMF local antenna emissive $S$ values only in the incubator air surrounding the cell culture plate. Despite this limitation we measured and calculated the average irradiated electric field intensity $\mathrm{E}$, inside the culture medium. The maximal effects were measured at 950 and $1000 \mathrm{MHz}$, where Igk recombination levels for an EMF of E $0.4 \mathrm{~V} / \mathrm{m}$ are only half (Fig. 5A), or for one of $0.6 \mathrm{~V} / \mathrm{m} \mathrm{E}$ a quarter of those reported for same $\mathrm{E}$ values at $720 \mathrm{MHz}$ (Fig. 5B). E dose effects parallel the frequency dependency described for the antenna emitted power dose S. However, the cell medium electric properties mentioned above, (increased absorbance and polarization between 900 and $1000 \mathrm{MHz}$ ), cannot account for the frequency results shown in Fig. 5 for irradiations at constant electric field E values. Besides such intrinsic medium properties there must be also a major EMF frequency direct influence on the cellular components linked to recombination.

Various wireless network service providers use for mobile phone communication frequencies ranging between 700 and $2100 \mathrm{MHz}$. At $1 \mathrm{~cm}$ distance, during outgoing calls the measured emitted field E intensities

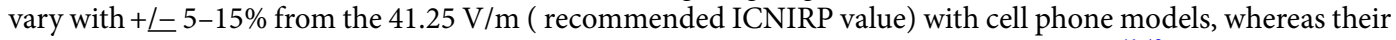
maximum output recorded power levels for a GSM1800 net varies between 0.25 and $1 \mathrm{~W}^{41,42}$. 
We assessed if the low dose $48 \mathrm{~h}$ EMF irradiations cause DNA DSBs and detectable $\gamma \mathrm{H} 2 \mathrm{AX}$ repair foci in exposed cells. From the levels of detected $\gamma \mathrm{H} 2 \mathrm{AX}$ repair foci of the EMF irradiated pre-B cells we could not reveal in exposed cells above background DNA DSBs repair activity (Fig. 6 compare panel A with C, G with I, and histograms in Fig. 6J). Using chromatin immunoprecipitation (ChIP) Savic et al. ${ }^{43}$ show considerable $\gamma \mathrm{H} 2 \mathrm{AX}$ accumulation near Jk5 in IgK locus after 24 h post STI571 (Imatinib) treatment of pre-Bs, but a dramatic more than two-fold decrease in $\gamma \mathrm{H} 2 \mathrm{AX}$ detection as cells were kept from 24 to $48 \mathrm{~h}$ post STI571 treatment ${ }^{43}$. We could not detect above background $\gamma \mathrm{H} 2 \mathrm{AX}$ foci levels in IMA or GSK treated cells after $48 \mathrm{~h}$ culture growth. This could be due either to a considerable post RAG DSBs repair recovery, or to a reduced sensitivity of our immunofluorescence assay (less sensitive than ChIP in detecting $\gamma \mathrm{H} 2 \mathrm{AX}$ ). The onset of DNA DSBs either prior to or during pre-B cells maturation inhibits rag1, 2 transcription $^{44}$ and reduces the levels of Igk locus rearrangement events ${ }^{45}$. These cellular stress effects are caused by ataxia teleangiectasia mutated (ATM) kinase either via NF-kB, FOXO1 signaling ${ }^{44,46}$ or via GADD45a inhibition ${ }^{45}$, both pathways directly targeting rag genes transcription levels. If very few EMF induced DSBs (below those detectable by $\gamma \mathrm{H} 2 \mathrm{AX}$ foci assay), or breaks already repaired before our cell harvests could have reduced RAG expression in our experiments(via ATM kinase) this could explain our observed reduced recombination effects. We used in our experiments two RAG induction stimuli, IMA sensitive to ATM kinase via GADD45a inhibition ${ }^{44-46}$ and the second GSK690693 AKT-inhibitor insensitive to this signaling pathway ${ }^{19}$. If very few EMF induced DNA DSBs would have reduced RAG expression prior to, or during drug action, one would have expected experiments to show a more accentuated recombination reduction for IMA than that obtained for GSK treatment. Instead, the experimental data in Figs. 3B, 4, 5 and Table 1 show for both drugs very similar EMF induced reduction of $I g k$ loci rearrangement levels(if not even slightly more pronounced reduction for GSK). IMA although a more potent RAG inducer than GSK has the disadvantage that post recombination blocks cells in Go phase preventing further their division ${ }^{36,47-49}$. On the contrary, the AKT inhibitor GSK-690693 not only is a weaker RAG induction stimulus (closer to the one physiologically occurring in small pre-B cells $)^{50,51}$ but also enables cells to divide prior to and after Igk loci rearrangements and protect their progress to the next stage of development ${ }^{19}$. Because our PCR assay intentionally uses the amount of templating genomic DNA from the same number of 2 millions harvested cells, replication would have "diminished the EMF recombination reduction" in GSK treated cells in contrast to those incubated with IMA (the later, on the contrary, "freezes" the EMF effect on BCL2 maintained survivors). As pointed earlier, in treated cells, both drugs show very similar EMF induced reduction of rearrangements in treated cells. Although we cannot fully refute that the observed EMF recombination effects may have been caused in irradiated pre-B cells by undetectable DNA DSBs via ATM, the line of evidence gathered from our experiments in Figs. 4, 5, 6 and the arguments presented above for the comparative IMA/GSK treatments make this mechanism a less likely candidate for their account.

Indirectly our work addresses the longstanding question of how innocuous low dose EMF irradiation from our telecommunication devices may be and whether it may affect the immunity of our organisms. It remains only to our speculation to extend the observed recombination effects induced by small EMFs from an in vitro culture system to the in vivo situation on the ability of irradiated B cells to elicit an unaltered antibody response to antigen challenge.

\section{Methods}

Materials. DNA oligonucleotides were purchased from Life Technologies and IDT DNA: Vk degenerate primer 5' GCTGCAGSTTCAGTGGCAGTGGCAGTGGRTCWGGRAC 3' where $\mathrm{S}$ is $\mathrm{G}$ or $\mathrm{C}$, $\mathrm{R}$ is A or G, W is T or A, Jk2-1 primer 5' CAAAACCCTCCCTAGGTAGACAATTATCCCTC 3' and Jk2-2 primer 5' GGACAG TTTTCCCTCCTTAACACCTGATCTG 3'. For Histone H1 gene control amplifications the following primers were used: H1fw 5' GGCTGCTATCCAGGCAGAGAAGAACCG 3', H1rv: 5' GCTTTGGAGGCGCCTTCT TGGGCTTG 3'.

Murine pre B cells transformed with Abelson virus (v-Abl preB, A70 line, that harbor a E $\mu$-Bcl2 transgene) were a kind gift from Barry Sleckman Duke University ${ }^{47}$. The cells were maintained in RPMI 1640 medium, supplemented with $10 \%$ FBS (both from GIBCO), $50 \mu \mathrm{M} 2$-mercaptoetanol and induced at $0.5 \times 10^{6} \mathrm{cells} / \mathrm{ml}$ density either with $3 \mu \mathrm{M}$ Imatinib Mesylate (IMA) (SIGMA-ALDRICH) or with $10 \mu \mathrm{M}$ GSK-690693(GSK)( GLAXOSMITHKLINE, SELLECK-chem) in solutions with $0.1 \%$ DMSO. After $48 \mathrm{~h}$ the cells were collected and analyzed using the nested PCR described below.

Pre- $B$ Cells irradiation was performed with a $1 \mathrm{~Hz}-1.224 \mathrm{GHz}, 13 \mathrm{dBm}$ radiofrequency generator (Hameg Instruments $1 \mathrm{~Hz}-1.2 \mathrm{GHz}$ programmable synthesizer HM8134-3, used throughout our study as emission generator) using a broadband irradiating $800 \mathrm{MHz}-3 \mathrm{GHz}$ LTE ATK-LOG ALP logarithmic antenna, in a regular $\mathrm{CO}_{2}$ incubator (SANYO Electric Co. MCO-17AIC), with $\mathrm{CO}_{2} 5$ vol. $\%$, and $95 \%$ purified water humidity. Cells were grown at $37^{\circ} \mathrm{C}$ in $5 \mathrm{ml}$ medium in standard six flat bottom wells ( $16.8 \mathrm{ml}$ capacity) polystyrene lidded plates (Corning Costar), which were always positioned in the same place with respect to the incubator walls (in the center of the incubator, see Supplemental material Fig. 1Sa) and the emission antenna (antenna central guiding label positioned midway between wells 3 and 6 at $2.4 \mathrm{~cm}$ above the mid plane of the plate, see supplementary Fig. 1S). Two parallel sets of experiments were performed with wells $1,2,3$ containing cells stimulated with $3 \mu \mathrm{M}$ IMA, whereas wells 4, 5 and 6 cells were stimulated with $10 \mu \mathrm{M}$ GSK (Fig. 1SB).

Two steps nested PCR reactions for $\mathrm{K}$ locus recombination. Template DNA was prepared for PCR using a modified technique developed by Schlissel ${ }^{37}$. Pre-B A-70 v-Abl cells were harvested after $48 \mathrm{~h}$ incubation with $\mathrm{IMA}^{36,47}, \mathrm{GSK}^{19}$ or unstimulated. Cultured cells $\left(2 \times 10^{6}-2\right.$ millions) were pelleted for $15 \mathrm{~s}$ in a microfuge, washed once in PBS(phosphate saline buffer $\mathrm{pH} 7.2$ ), resuspended in $200 \mu \mathrm{l} \mathrm{PCR} \mathrm{lysis} \mathrm{buffer}(10 \mathrm{mM}$ Tris $\mathrm{pH}$ 8.4, $2.5 \mathrm{mM} \mathrm{MgCl} 2,50 \mathrm{mM} \mathrm{KCl}, 200 \mu \mathrm{g} / \mathrm{ml}$ gelatin, 0.45\% NP40, 0.45\% Tween-20 (CALBIOCHEM), and $60 \mu \mathrm{g} /$ $\mathrm{ml}$ Proteinase $\mathrm{K}$ (Boehringer), and incubated at $56^{\circ} \mathrm{C}$ for $3 \mathrm{~h}$ followed by $15 \mathrm{~min}$ at $95^{\circ} \mathrm{C}$. Dilution of templates 
was done with PCR lysis buffer without Proteinase K. Two successive PCR amplifications were done in a final volume of $50 \mu \mathrm{l}$ containing 2 to $5 \mu \mathrm{l}$ template DNA, $10 \mathrm{mM}$ Tris- $\mathrm{HCl}(\mathrm{pH} \mathrm{8.4}$; at room temperature), $50 \mathrm{mM}$ $\mathrm{KCl}, 2.5 \mathrm{mM} \mathrm{MgCl} 2,200 \mu \mathrm{g} / \mathrm{ml}$ gelatin, $0.2 \mathrm{mM}$ of all four dNTPs (all from ThermoFisher scientific), each oligonucleotide primer at $0.4 \mu \mathrm{M}$ (20 pmol each primer per reaction), and $1 \mathrm{U}$ TAQ DNA polymerase (GoTaq PROMEGA) in nested reactions. First step PCR reactions for 25 cycles use Vk, and Jk2-1primers. In the second step various dilutions (from $4 \mu \mathrm{ls}$ 1:100 dilution of first PCR to $0.5 \mu \mathrm{ls}$ of the first undiluted PCR) are individually used to template the second PCR reactions to which Vk and Jk2-2 primers are added and an additional round of 30 cycles amplification is performed. Cycling steps were: an initial $1 \mathrm{~min}$ denaturation at $94^{\circ} \mathrm{C}$, then repeated cycles each, $30 \mathrm{~s}$ at $94{ }^{\circ} \mathrm{C}, 0.5 \mathrm{~min}$ annealing at $50^{\circ} \mathrm{C}$, and $1.5 \mathrm{~min}$ polymerization at $72{ }^{\circ} \mathrm{C}$. A final additional 5 min extension step was performed at $72{ }^{\circ} \mathrm{C}^{36,37}$. PCR products were resolved on $1.5 \%$ agarose gel, stained either with ethidium bromide or Sybr Green (THERMOFISHER scientific) and visualized using the PharosFX system (BIORAD). The bands intensities were quantified using QuantityOne software.

Kappa locus amplification products analysis. Each Vk-Jk2 product band density of the gel scan image is quantified and the ratio between the densitometry value of the PCR product band detected from cells grown in the presence of EMF and the corresponding one without field exposure (EMF+/EMF-, Cell Recomb. Fr., Figs. 3, $4,5)$ reports the changes in $\mathrm{V}(\mathrm{D}) \mathrm{J}$ recombination occurred upon each cell treatment (IMA/GSK). To normalize for DNA extraction levels we performed similar PCR amplifications from the same amount of template DNA using a pair of primers $\mathrm{H} 1 \mathrm{fw}$ and H1rv to specifically detect the histone H1 gene.

$\mathrm{H}$ 2AX foci analysis for irradiation induced DNA damage cellular response. Cells were grown under similar conditions with those described above for recombination assays. Additionally, a DNA DSBs control cell lot either uninduced or one for each RAG stimulus (IMA or GSK) was exposed to a quick 20 min X ray cumulative dose exposure of 1 Gray (X-ray irradiation with a slow rate 50-milligray /min with a Mevatron Primus $2 \mathrm{D}, 6 \mathrm{MV}$, SIEMENS instrument) prior to their harvest. The samples were irradiated at $100 \mathrm{~cm}$ distance from the source axis, the field size being of $30 \times 30 \mathrm{~cm}$. The dosimetry was performed using a water phantom $(1 \mathrm{~cm}$ water depth). Symmetry and homogeneity were checked, the dose proved to be homogenous throughout the sample in the used plates. For all treatments, twenty minutes after harvest, instead of extracting DNA, the cells from each individual culture type were separately spread onto clean designated slide sets using a Cytospin Centrifuge. The cells were then fixed with paraformaldehyde, permeabilized with Triton X and then doubly stained with: (a) Hoechst 33342 dye (THERMO SCIENTIFIC) (for their nuclei-DNA total staining in blue) and (b) immunofluorescently with primary unlabeled anti $\gamma \mathrm{H} 2 \mathrm{AX}$ antibodies of mouse antigen specificity complemented with secondary Cy2 labeled anti primary source antibodies (rat anti mouse IgG Cy2 detection antibodies-green)(both from SIGMA ALDRICH); to identify in green the DSB repairing $\gamma \mathrm{H} 2 \mathrm{AX}$ foci ${ }^{40}$. The slides were examined with a fluorescence microscope (OLYMPUS BX60) with adequate filter for the fluorophores, and images of the nuclei and $\gamma \mathrm{H} 2 \mathrm{AX}$ foci recorded with a camera connected to the microscope. The images were analyzed using specific analysis software to quantify the number of foci per each cell treatment type, and morphologically to indicate their level of dispersion or nuclear positioning (see Fig. 6).

Western blot analysis for endogenous RAG time course induction in pre-B cells (Supplemental material Fig. 2S) following IMA/GSK treatment was performed as previously described in our work using anti RAG1 and anti RAG2 mouse monoclonal antibodies (gift from Dr. David G. Schatz, Yale University), and control sample purified murine core RAG1(384-1040) and coreRAG2 (1-387) fused to Maltose binding protein (MBP-40kD) which were transiently expressed in co-transfected HEK293T cells ${ }^{52}$ (source ATCC CRL-3216).

Absorption spectra measurements were made using two identical broadband $(0.8-16 \mathrm{GHz})$ horn antennas facing each-other and placed at $1 \mathrm{~m}$ distance. The measurement subjected sample was placed in close proximity $(1 \mathrm{~cm})$ of the receiver whereas the emission antenna (supplementary Fig. $4 \mathrm{~S}$ a and b), was coupled to the generator. The receiver antenna was connected to a commercial Spectrum Analyzer (Keysight-AGILENT-HP N9935A, 0.1- $9 \mathrm{GHz}$ ) on which the received signals were recorded and analyzed. The shown absorption spectra in Fig. 2 were obtained after subtraction of the background spectra with no liquid sample placed in the container in front of the receiver antenna. The deionized water used for measurement has the conductivity $<5 \mu \mathrm{S} / \mathrm{cm}$, whereas the used unfiltered tap water with ions has the following characteristic measured chemical parameters per liter (l) $\mathrm{pH}$ 6.5-9.5, Conductivity $<800 \mu \mathrm{S} / \mathrm{cm}$, ammonia $<0.5 \mathrm{mg} / \mathrm{l}$, free residual Chlorine $<0.5 \mathrm{mg} / \mathrm{l}, \mathrm{Fe}<200 \mu \mathrm{g} / \mathrm{l}$, $\mathrm{Mn}<50 \mu \mathrm{g} / \mathrm{l}, \mathrm{Al}<200 \mu \mathrm{g} / \mathrm{l}$, nitrites $<0.5 \mathrm{mg} / \mathrm{l}$, nitrates $<50 \mathrm{mg} / \mathrm{l}$, Borate salts $1 \mathrm{mg} / \mathrm{l}$, Chlorides $250 \mathrm{mg} / \mathrm{l}$, Sulphates $250 \mathrm{mg} / \mathrm{l}, 65 \mathrm{mg} / \mathrm{l}$ calcium carbonate, Hardness $<5$ degrees $(\mathrm{dGH})$.

Received: 29 November 2020; Accepted: 31 May 2021

Published online: 16 June 2021

\section{References}

1. Tonegawa, S. Somatic generation of antibody diversity. Nature 302, 575-581 (1983).

2. Kim, M. S., Lapkouski, M., Yang, W. \& Gellert, M. Crystal structure of the V(D)J recombinase RAG1-RAG2. Nature 518, 507-511. https://doi.org/10.1038/nature14174 (2015).

3. Sadofsky, M. J. The RAG proteins in V(D)J recombination: more than just a nuclease. Nucleic Acids Res. 29, 1399-1409 (2001).

4. Schatz, D. G. \& Ji, Y. Recombination centres and the orchestration of V(D)J recombination. Nat. Rev. Immunol 11, 251-263. https:// doi.org/10.1038/nri2941 (2011).

5. Schatz, D. G. \& Swanson, P. C. V(D)J recombination: mechanisms of initiation. Annu. Rev. Genet. 45, 167-202. https://doi.org/10. 1146/annurev-genet-110410-132552 (2011). 
6. Herzog, S., Reth, M. \& Jumaa, H. Regulation of B-cell proliferation and differentiation by pre-B-cell receptor signalling. Nat. Rev. Immunol. 9, 195-205. https://doi.org/10.1038/nri2491 (2009).

7. Peschon, J. J. et al. Early lymphocyte expansion is severely impaired in interleukin 7 receptor-deficient mice. J. Exp. Med. 180, 1955-1960. https://doi.org/10.1084/jem.180.5.1955 (1994).

8. O'Shea, J. J. \& Plenge, R. JAK and STAT signaling molecules in immunoregulation and immune-mediated disease. Immunity 36, 542-550. https://doi.org/10.1016/j.immuni.2012.03.014 (2012).

9. Goetz, C. A., Harmon, I. R., O’Neil, J. J., Burchill, M. A. \& Farrar, M. A. STAT5 activation underlies IL7 receptor-dependent B cell development. J. Immunol. 172, 4770-4778. https://doi.org/10.4049/jimmunol.172.8.4770 (2004).

10. Yao, Z. et al. Stat5a/b are essential for normal lymphoid development and differentiation. Proc. Natl. Acad. Sci. U. S. A. 103, 1000-1005. https://doi.org/10.1073/pnas.0507350103 (2006).

11. Cooper, A. B. et al. A unique function for cyclin D3 in early B cell development. Nat. Immunol. 7, 489-497. https://doi.org/10. 1038/ni1324 (2006).

12. Jiang, Q. et al. Distinct regions of the interleukin-7 receptor regulate different Bcl2 family members. Mol. Cell Biol. 24, 6501-6513. https://doi.org/10.1128/MCB.24.14.6501-6513.2004 (2004).

13. Ramadani, F. et al. The PI3K isoforms p110alpha and p110delta are essential for pre-B cell receptor signaling and B cell development. Sci Signal 3, ra60. https://doi.org/10.1126/scisignal.2001104 (2010).

14. Amin, R. H. \& Schlissel, M. S. Foxo1 directly regulates the transcription of recombination-activating genes during B cell development. Nat. Immunol. 9, 613-622. https://doi.org/10.1038/ni.1612 (2008).

15. Dengler, H. S. et al. Distinct functions for the transcription factor Foxol at various stages of B cell differentiation. Nat. Immunol. 9, 1388-1398. https://doi.org/10.1038/ni.1667 (2008).

16. Eijkelenboom, A. \& Burgering, B. M. FOXOs: signalling integrators for homeostasis maintenance. Nat. Rev. Mol. Cell Biol. 14, 83-97. https://doi.org/10.1038/nrm3507 (2013).

17. Kuo, T. C. \& Schlissel, M. S. Mechanisms controlling expression of the RAG locus during lymphocyte development. Curr. Opin. Immunol. 21, 173-178. https://doi.org/10.1016/j.coi.2009.03.008 (2009).

18. Ozes, O. N. et al. NF-kappaB activation by tumour necrosis factor requires the Akt serine-threonine kinase. Nature 401, 82-85. https://doi.org/10.1038/43466 (1999).

19. Ochodnicka-Mackovicova, K. et al. NF-kappaB and AKT signaling prevent DNA damage in transformed pre-B cells by suppressing RAG1/2 expression and activity. Blood 126, 1324-1335. https://doi.org/10.1182/blood-2015-01-621623 (2015).

20. Ochiai, K. et al. A self-reinforcing regulatory network triggered by limiting IL-7 activates pre-BCR signaling and differentiation. Nat. Immunol. 13, 300-307. https://doi.org/10.1038/ni.2210 (2012).

21. Inlay, M. A., Tian, H., Lin, T. \& Xu, Y. Important roles for $\mathrm{E}$ protein binding sites within the immunoglobulin kappa chain intronic enhancer in activating Vkappa Jkappa rearrangement. J. Exp. Med. 200, 1205-1211. https://doi.org/10.1084/jem.20041135 (2004).

22. Herzog, S. et al. SLP-65 regulates immunoglobulin light chain gene recombination through the PI(3)K-PKB-Foxo pathway. Nat. Immunol. 9, 623-631. https://doi.org/10.1038/ni.1616 (2008).

23. Lieber, M. R., Yu, K. \& Raghavan, S. C. Roles of nonhomologous DNA end joining, V(D)J recombination, and class switch recombination in chromosomal translocations. DNA Repair (Amst) 5, 1234-1245. https://doi.org/10.1016/j.dnarep.2006.05.013 (2006).

24. Marculescu, R., Le, T., Simon, P., Jaeger, U. \& Nadel, B. V(D)J-mediated translocations in lymphoid neoplasms: a functional assessment of genomic instability by cryptic sites. J. Exp. Med. 195, 85-98 (2002).

25. Delimaris, J., Tsilimigaki, S., Messini-Nicolaki, N., Ziros, E. \& Piperakis, S. M. Effects of pulsed electric fields on DNA of human lymphocytes. Cell Biol. Toxicol. 22, 409-415. https://doi.org/10.1007/s10565-006-0105-1 (2006).

26. Phillips, J. L., Singh, N. P. \& Lai, H. Electromagnetic fields and DNA damage. Pathophysiology 16, 79-88. https://doi.org/10.1016/j. pathophys.2008.11.005 (2009).

27. Olive, P. L. \& Banath, J. P. The comet assay: a method to measure DNA damage in individual cells. Nat. Protoc. 1, 23-29. https:// doi.org/10.1038/nprot.2006.5 (2006).

28. Phillips, J. L. et al. DNA damage in Molt-4 T- lymphoblastoid cells exposed to cellular telephone radiofrequency fields in vitro. Bioelectrochem. Bioenerg. 45, 103-110. https://doi.org/10.1016/s0302-4598(98)00074-9 (1998).

29. Mashevich, M. et al. Exposure of human peripheral blood lymphocytes to electromagnetic fields associated with cellular phones leads to chromosomal instability. Bioelectromagnetics 24, 82-90. https://doi.org/10.1002/bem.10086 (2003).

30. Leal, B. Z., Szilagyi, M., Prihoda, T. J. \& Meltz, M. L. Primary DNA damage in human blood lymphocytes exposed in vitro to 2450 MHz radiofrequency radiation. Radiat. Res. 153, 479-486. https://doi.org/10.1667/0033-7587(2000)153[0479:pddihb]2.0.co;2 (2000).

31. McNamee, J. P. et al. No evidence for genotoxic effects from $24 \mathrm{~h}$ exposure of human leukocytes to $1.9 \mathrm{GHz}$ radiofrequency fields. Radiat. Res. 159, 693-697. https://doi.org/10.1667/0033-7587(2003)159[0693:nefgef]2.0.co;2 (2003).

32. Stronati, L. et al. $935 \mathrm{MHz}$ cellular phone radiation. An in vitro study of genotoxicity in human lymphocytes. Int. J. Radiat. Biol. 82, 339-346. https://doi.org/10.1080/09553000600739173 (2006).

33. Hook, G. J. et al. Measurement of DNA damage and apoptosis in Molt-4 cells after in vitro exposure to radiofrequency radiation. Radiat. Res. 161, 193-200. https://doi.org/10.1667/rr3127 (2004).

34. Muljo, S. A. \& Schlissel, M. S. A small molecule Abl kinase inhibitor induces differentiation of Abelson virus-transformed pre-B cell lines. Nat. Immunol. 4, 31-37. https://doi.org/10.1038/ni870 (2003).

35. Wilson, M. K., McWhirter, S. M., Amin, R. H., Huang, D. \& Schlissel, M. S. Abelson virus transformation prevents TRAIL expression by inhibiting FoxO3a and NF-kappaB. Mol. Cells 29, 333-341. https://doi.org/10.1007/s10059-010-0029-8 (2010).

36. Carmona, L. M., Fugmann, S. D. \& Schatz, D. G. Collaboration of RAG2 with RAG1-like proteins during the evolution of V(D)J recombination. Genes Dev. 30, 909-917. https://doi.org/10.1101/gad.278432.116 (2016).

37. Schlissel, M. S. \& Baltimore, D. Activation of immunoglobulin kappa gene rearrangement correlates with induction of germline kappa gene transcription. Cell 58, 1001-1007. https://doi.org/10.1016/0092-8674(89)90951-3 (1989).

38. Gregson, S. M., McCormick, J. \& Parini, C. Principles of Planar Near-Field Antenna Measurements 35-61 (The Institution of Engineering and Technology, London, 2007).

39. Helmink, B. A. et al. H2AX prevents CtIP-mediated DNA end resection and aberrant repair in G1-phase lymphocytes. Nature 469, 245-249. https://doi.org/10.1038/nature09585 (2011).

40. Huang, X. \& Darzynkiewicz, Z. Cytometric assessment of histone H2AX phosphorylation: a reporter of DNA damage. Methods Mol Biol 314, 73-80. https://doi.org/10.1385/1-59259-973-7:073 (2006).

41. I. C. o. N.-I. R. P. Principles for non-ionizing radiation protection. Health Phys. 118, 477-482. https://doi.org/10.1097/hp.00000 $00000001252(2020)$

42. Isabona, J. \& Srivastava, V. M. (2017) Cellular mobile phone-a technical assessment on electromagnetic radiation intensity on human safety. IEEE, 271-274, Doi: https://doi.org/10.1109/NIGERCON.2017.8281899

43. Savic, V. et al. Formation of dynamic gamma-H2AX domains along broken DNA strands is distinctly regulated by ATM and MDC1 and dependent upon H2AX densities in chromatin. Mol. Cell 34, 298-310. https://doi.org/10.1016/j.molcel.2009.04.012 (2009).

44. Fisher, M. R., Rivera-Reyes, A., Bloch, N. B., Schatz, D. G. \& Bassing, C. H. Immature lymphocytes inhibit Rag1 and Rag2 transcription and V(D)J recombination in response to DNA double-strand breaks. J. Immunol. 198, 2943-2956. https://doi.org/10. 4049/jimmunol.1601639 (2017). 
45. Steinel, N. C. et al. The ataxia telangiectasia mutated kinase controls Igkappa allelic exclusion by inhibiting secondary Vkappa-toJkappa rearrangements. J. Exp. Med. 210, 233-239. https://doi.org/10.1084/jem.20121605 (2013).

46. Ochodnicka-Mackovicova, K. et al. The DNA damage response regulates RAG1/2 expression in pre-B cells through ATM-FOXO1 signaling. J. Immunol. 197, 2918-2929. https://doi.org/10.4049/jimmunol.1501989 (2016).

47. Bredemeyer, A. L. et al. ATM stabilizes DNA double-strand-break complexes during V(D)J recombination. Nature 442, 466-470. https://doi.org/10.1038/nature04866 (2006).

48. Hantschel, O., Rix, U. \& Superti-Furga, G. Target spectrum of the BCR-ABL inhibitors imatinib, nilotinib and dasatinib. Leuk. Lymphoma 49, 615-619. https://doi.org/10.1080/10428190801896103 (2008).

49. Marinelli Busilacchi, E. et al. Immunomodulatory effects of tyrosine kinase inhibitor in vitro and in vivo study. Biol. Blood Marrow Transplant. 24, 267-275. https://doi.org/10.1016/j.bbmt.2017.10.039 (2018).

50. Borghesi, L. et al. B lineage-specific regulation of $\mathrm{V}(\mathrm{D}) \mathrm{J}$ recombinase activity is established in common lymphoid progenitors. J. Exp. Med. 199, 491-502. https://doi.org/10.1084/jem.20031800 (2004).

51. Grawunder, U. et al. Down-regulation of RAG1 and RAG2 gene expression in preB cells after functional immunoglobulin heavy chain rearrangement. Immunity 3, 601-608. https://doi.org/10.1016/1074-7613(95)90131-0 (1995).

52. Ciubotaru, M. et al. The architecture of the 12RSS in V(D)J recombination signal and synaptic complexes. Nucleic Acids Res. 43, 917-931. https://doi.org/10.1093/nar/gku1348 (2015).

\title{
Acknowledgements
}

This work was supported by the following projects: PN-III-P4-ID-PCE-2016-0502 Acronym V(D)JMYC contract 178/2017, 5/5.1/ELI-RO, RDI 2016 acronym "BIOSAFE" Contract Nr. 17/2016 and PN-III-P1-1.2-PCCDI-2017 acronym "ONCORAD" Contract Nr. 64/2018. We would also wish to acknowledge support from COMTEST srl. company from Dr. ing. Radu Mateescu in measuring probe absorption and discussions of the manuscript with Dr. Gabriel Banciu, D. Liviu Nedelcu and Dragos Geambasu.

\section{Author contributions}

E.I. has performed all the cell irradiation experiments, maintained the pre-B cells in culture, performed PCR from genomic DNA and quantified the amplification results. A.M. and M.S. have performed all the experiments to measure the EMF parameters used in irradiation, absorption spectra, power flux density and electric field intensity measurements. M.T. has performed the experiments to detect and quantify the $\gamma \mathrm{H} 2 \mathrm{AX}$ foci whereas D.S. helped in interpreting the results of their foci/cell analysis. M.C. has designed the experiments, performed the analysis and interpretation of the cell irradiation experiments, supervised experiments and wrote the manuscript. All authors reviewed the manuscript.

\section{Competing interests}

The authors declare no competing interests.

\section{Additional information}

Supplementary Information The online version contains supplementary material available at https://doi.org/ 10.1038/s41598-021-91790-3.

Correspondence and requests for materials should be addressed to M.C.

Reprints and permissions information is available at www.nature.com/reprints.

Publisher's note Springer Nature remains neutral with regard to jurisdictional claims in published maps and institutional affiliations.

\begin{abstract}
(c) (i) Open Access This article is licensed under a Creative Commons Attribution 4.0 International cc) License, which permits use, sharing, adaptation, distribution and reproduction in any medium or format, as long as you give appropriate credit to the original author(s) and the source, provide a link to the Creative Commons licence, and indicate if changes were made. The images or other third party material in this article are included in the article's Creative Commons licence, unless indicated otherwise in a credit line to the material. If material is not included in the article's Creative Commons licence and your intended use is not permitted by statutory regulation or exceeds the permitted use, you will need to obtain permission directly from the copyright holder. To view a copy of this licence, visit http://creativecommons.org/licenses/by/4.0/.
\end{abstract}

(C) The Author(s) 2021 